AECD-3803

FACTORS AFFECTING PROPERTIES OF EXTRUDED COMPACTS OF CRYSTAL BAR ZIRCONIUM.

By

S. V. Arnold

Massachusetts Inst. of Tech., Metallurgical Project

Date Declassified: December 5, 1955

Photostat Price s__
Microfilm Price s
Avoilable from the
Office of Technical Services
Depertment of Conmerce
Washington $25, \mathrm{D} . \mathrm{C}$.


Iroa S. Y. Arnold

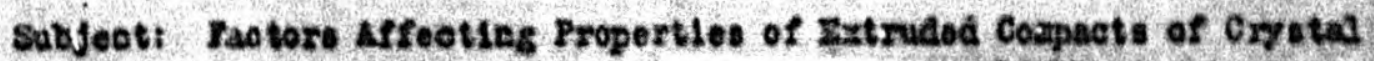
Har 21roentu

Dete I June 10, 19 lig

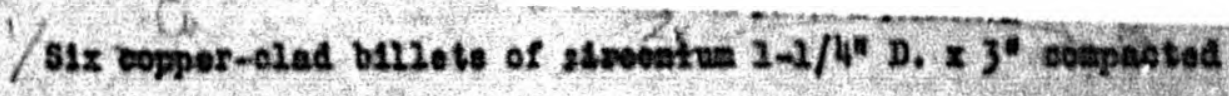

Ifee $1 / 2^{\prime}$ longthe of eryetal bar under 130,000 pes. proserure st $900^{\circ} \mathrm{C}$

wore extruded at the sase tesperature at $7.911,14: 1$, and 31.611 redue-

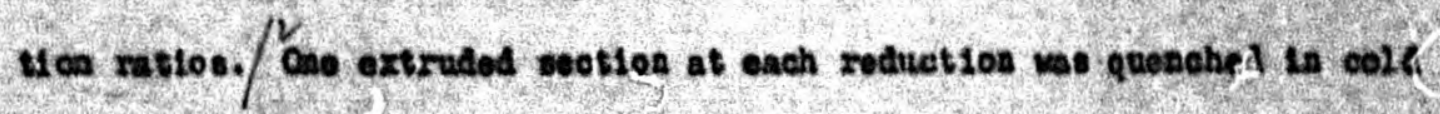

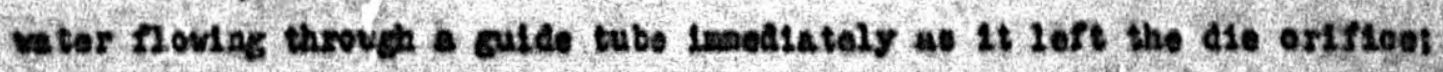
another at each of thepe esese reductions was alloved to cool In alr.

Compeoting techni gue folkowed that ind teated at proforablo of

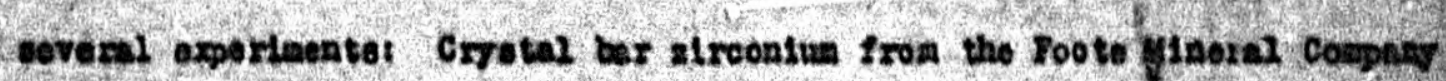

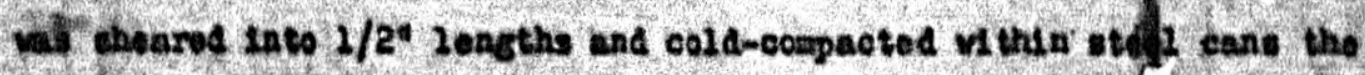
open ends of vateh vere then fitted vith dises and velded ofoned. Tho

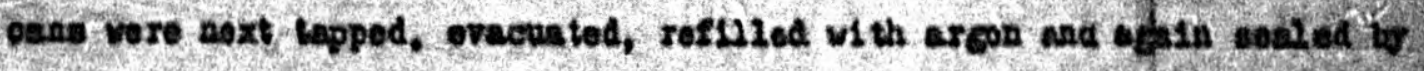
velaing. Hot compresalon at $900^{\circ} \mathrm{C}$ folloved. The veaperatare and preseure promotes ouffictent bending of the orratel bar chitike to alloy $\rightarrow$

the compact to bo otrigped of lte ateel cen and mechined for recanning. Blecher teaperatures introduce difficultios through eruapiling of the can during compacting. (It eoens possible that tochatques uny bo doveloped

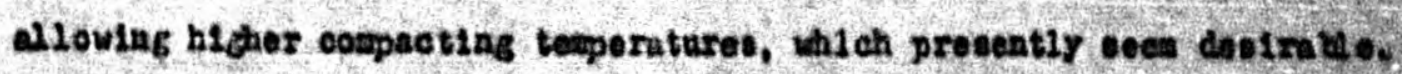
Lor precuuro, high tomperature coupscting within Indret1on-heated eraphlte moldo has been triod and appoars promlning. Complete tonding

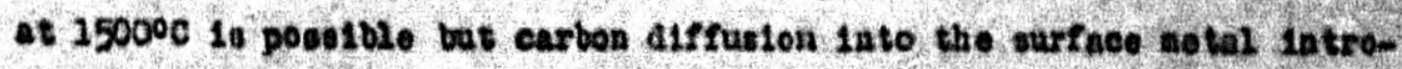
fuces screp $10 e s$ and a machining problen in removal of contasinatsd metal.) 
The cxeppacted blzzete vere cauned in h6-eage copper for extrustea. (Copper possesens adequate cuotility to serve at a jocker aaterial, but extruation tesperatura is 11 at tod by the $980^{\circ} \mathrm{C}$ copper-atreostus ontello

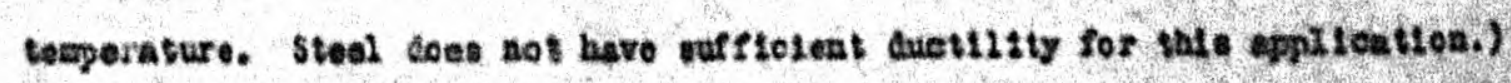
lxtruston of the blllets produchd seocth, cound rounds of

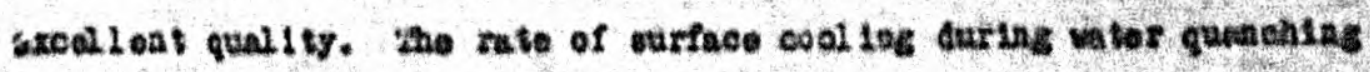
way have varied between the three reduetlons, thace veloolty of veler

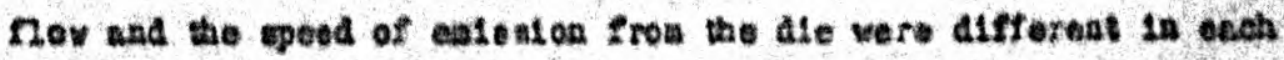
Inatanes. The mase of the differeat round sise and the tesperetane to

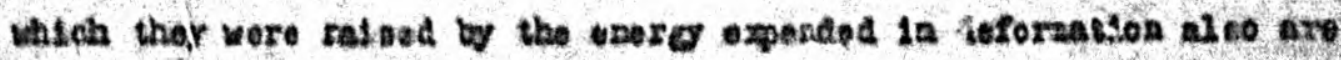
factors affecting the cooliag rate, both in water asi in alr.

Is is best to discues the ulorostructurat charecterteflas of tho extruciod nectloas before thelr sensilo prope rtied, stuce the foimar help to explate certaln pecul lart tles of the lether.

The Interprotation of mlerontruecures in thoee opectiens has

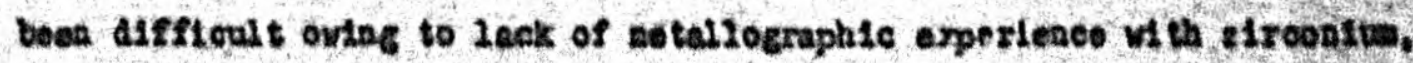
partieularily after sabricatiag of these procoluros.

Sose fastures of the water-quenched ruonde, hovever, ween to Indicata the condstion during and oubeguant to extrueton. of prisary

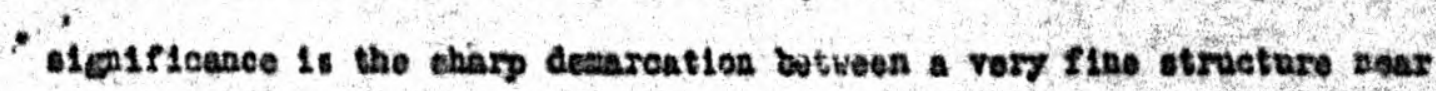
the ourface ne theee rounde end a conzer ege tral otructure (ean rigure $\mathrm{U}$ ). Lio outer sose conelinte mo etly of very ball, equi-axed grains and ocensional patches of ot ratiflod natal chowlag the goatimucus varying eradations of rofoetivi ty ersoclated of th a deformed latiloe for vith eralus Just reorgetaliszed from ouch a lattloe and stiliz rotalning the paront ortentation) as is IIgure 13. The outer atructure ahowed enallea craln olso nearer the eurface. in some cases so fino as to be irresolvablo. 


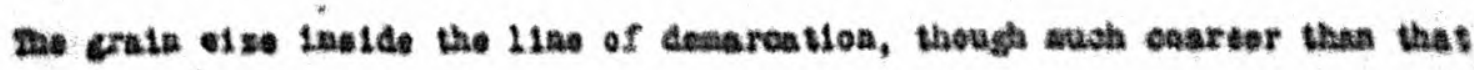

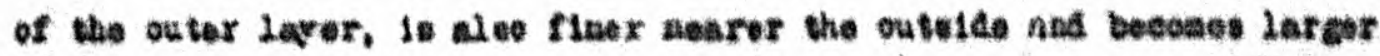
tovand the center of the round (ees riguree 10 and 2D). "Lore Laree.

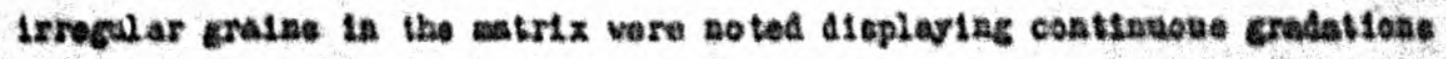

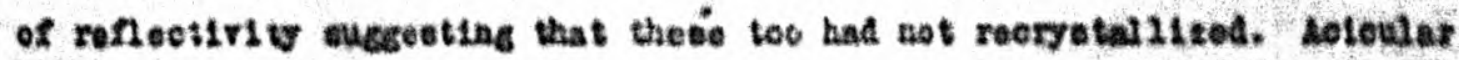

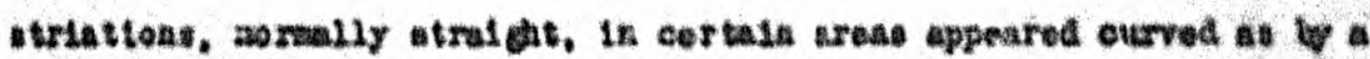
centlavous aletortion of the lattloe in further nubatantiation of the

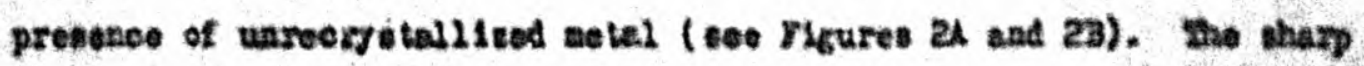

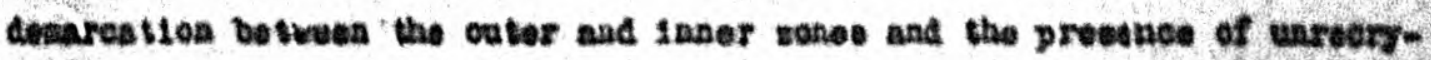
otall 1zed, yet destallar, gralne in each are taken to indieate thet two ghases oxieted durleg extruat on. The proseure of extrualon vould preeubably lavor malatenasice of the elceer-packed at pha phase. Salghty creator dosoration plus ourfaco frictloa wold presurably ratee the temporature of the outer netal above that of the Inver. polatsing to a bota phave condition in the outer portson of these round prior to cooling. The area of the outer zones cosprined $70 \%, 72$ and $76 \%$ of the extruded atroonlus crosemection for the $7.921,2412$ and 32.6:2 reduotion reopectively.

The al reool od rounds rotalaed very 11ttlo of the oore strueture fousd in the water-quenchod eoctions. Sasteed, the erain st se ineroased gradually from odgo to centar in a fantion euserenting that the thermal enore of cofomation had ralaed all but occablonal, local 1zod central areas to within the beta phase regian. Aocrystallization and erais exovth proceoded unt1 IIal ted by coaling - the outer graine wisch eooled firet naturally boing ealler than those furthor in. 
In all warostructures, It wast be otated, tivere seeas 21 the

Likal theod that way beta phase when wat retalned to roca tempenture.

Unbonded lalerfaces we re found over 'te ealire oroes ceetion of the 7.911 reduced rounds, but for hicher reda itione leok of bending we clesely relegatid to ourface or nearmeurfece intortacen (which apparently incurred greator contaninatioa, probebly furiag bot coepactingl.

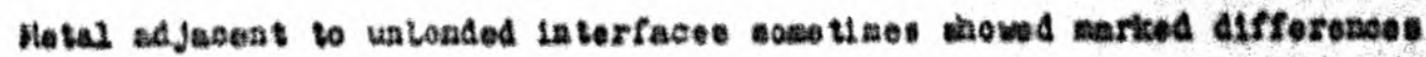
In cala olse from that of the wurrounding antrix (sen rigeure 20). Oraln

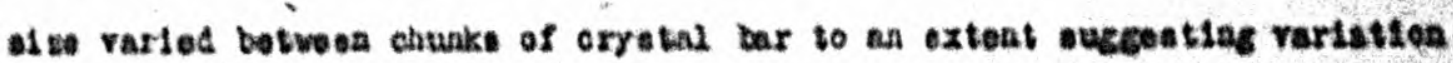

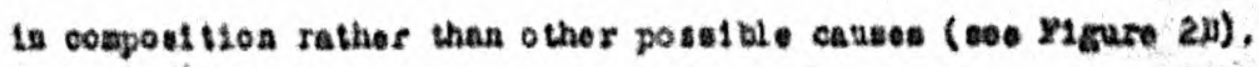
$+$ The propertied of tenatle epocisens fachtonod from the round are 11 stechin gable I and prosented eraphlesily la Figure 3. Hofere an assigs! s of the reault is at teapted. It ohould be otated that opeciness

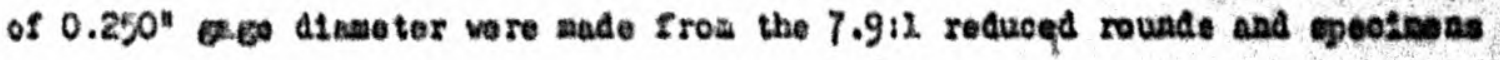

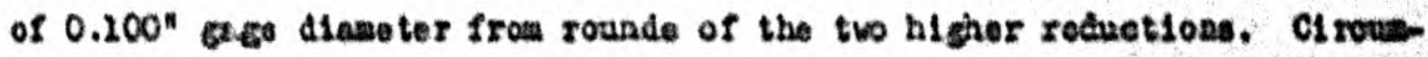
otantially, in opecimene from the water-queachod rounde these diameter. Included only the coarso-gralned core structure. Netallographdo exsminstion ovecented that thlo was alpha phase wal whlch lareely rucryotalleod after extrue10n. The alr-cooled rounds aro considered to have trannforned almoot ocopletely to bota phase durlag and aiter oxtrublon, leaving only a manll anount of centrally dieponed netal posalbly in the alpha conditien prior $w$ cooliag. The teanlle data therefore compare two disferent whorostructures wich an wecount in large part for the oteervoc defferences.

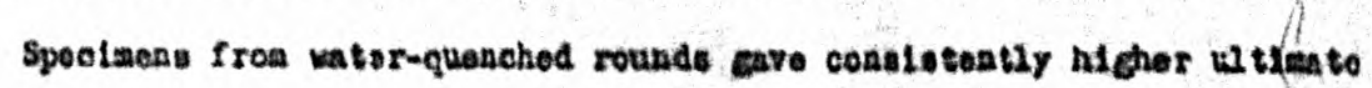
atreagth and ductility than those froa al r-cool ed rounds. The $20 x$ reduetiono In area of opeolmesa froa $7.9: 1$ reduction ratio are attributable to the

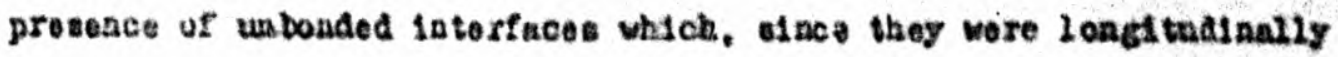


orlested, atd sol wfect as adversely the elongation values.

There are ecant ata with whtoh to eompare theee eubjeot values, but Bureau of Wines tatal etalianly extruded at reduotiens of 1411 and

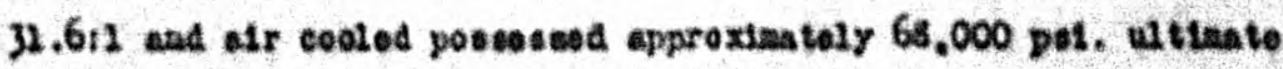
strasgth, 25\% elongation and $45 \%$ reduction of ares. File vould Indicate that the extruded coapact is oonstderably cofter and move huetile in Q Lagation. Hoverter, tho reduetion of area is lever than that of the Bureas of UIno antel, I rofloctian peitheps on the extent of bonates betweoa Lopftudinal interfaces of adjolnting cryatal bar chanke in the oxtrudod coopacts.

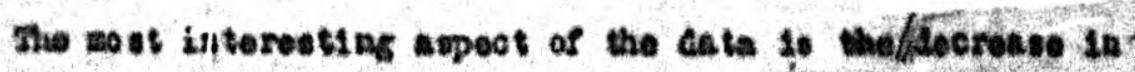

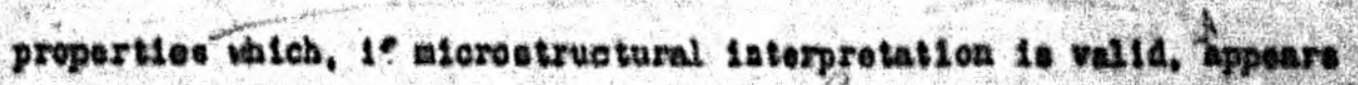
asecisted with trangformation into the phase aring extruaton. $/ 4$ oving to our radisientary kneviedgo of alreontua behavior in fabsication and dobstable posiblittle cugested to the alerootruetures of the enbjoct rowad. this phesosenon deserves further farestlention betore atsesptins ent cosclus lone. 
5xblo 1

Reteot of Cool ine wate frou ratrukion at $900 \%$ on Teasile Properties of zircostua Crystal Ther Cowpect

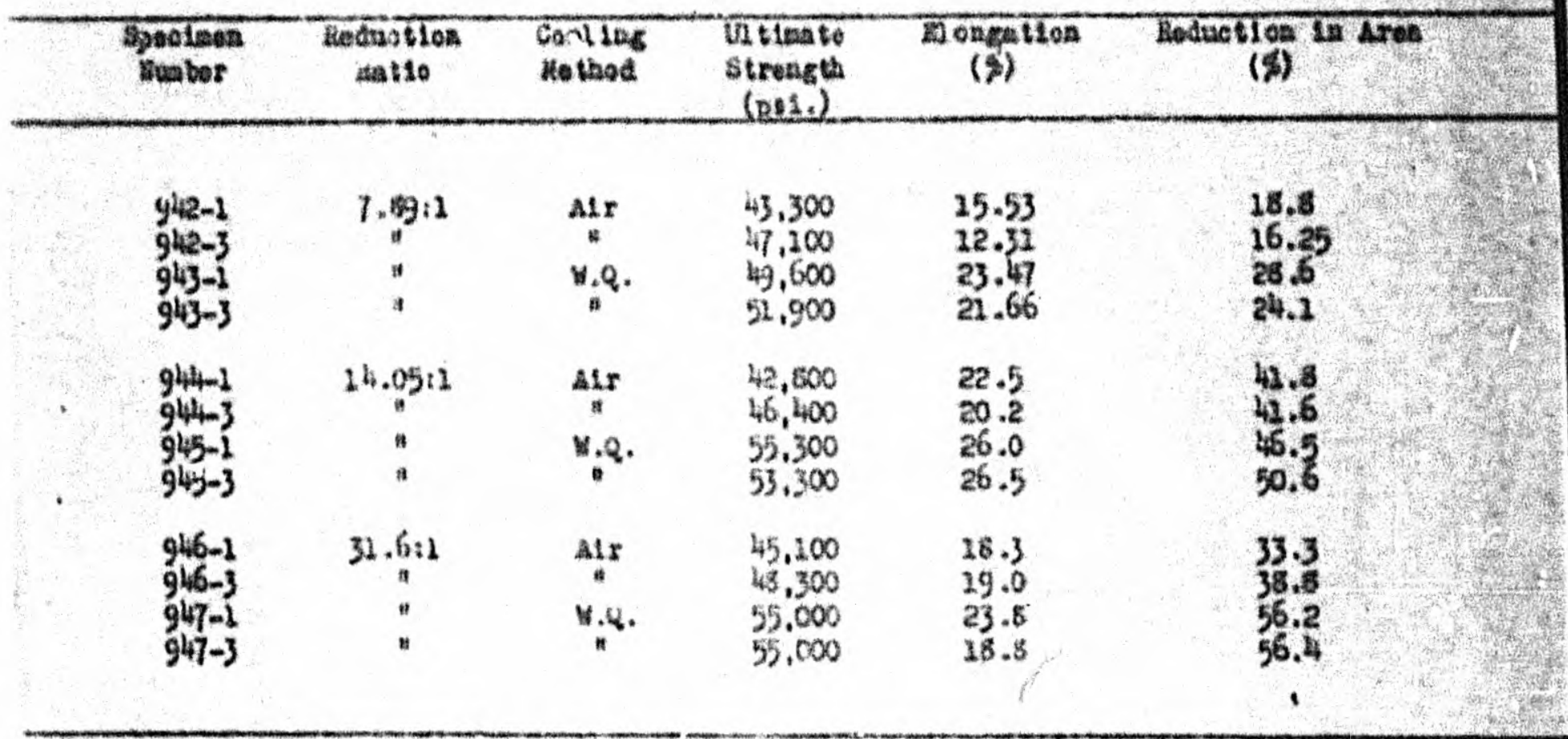

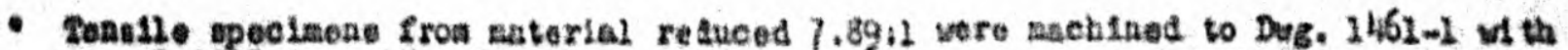

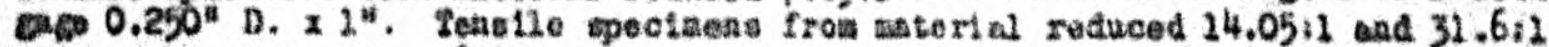
vero iachined to 1 hag. $1671-1$ vith $0.100^{\circ}$ D. $x 1^{\text {* }}$. 


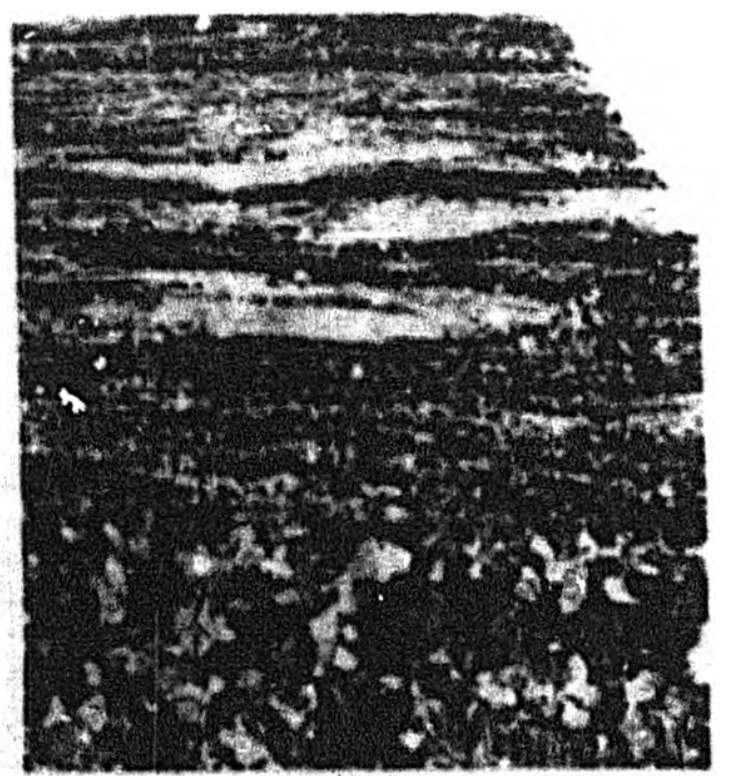

(A) Drascation botweea futer (Abova) and Janar zones. 14:1 Reducod dound. Veter vienched.

isagt tultiul section.

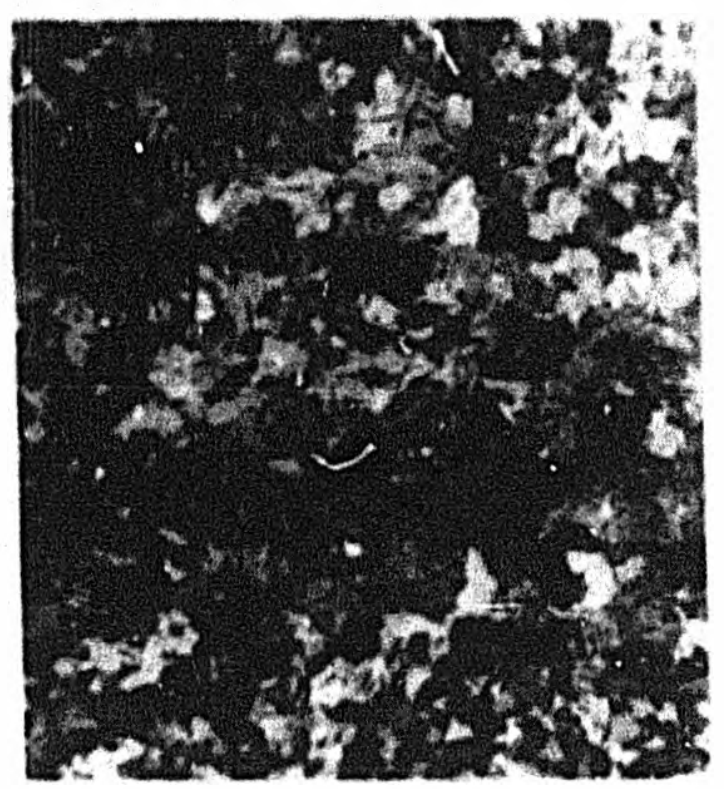

(c) Orain Size at Outer Portion of Inaer zone in 14:2 Baduced flound, Vater quenchod.

Lougltucinal Section.

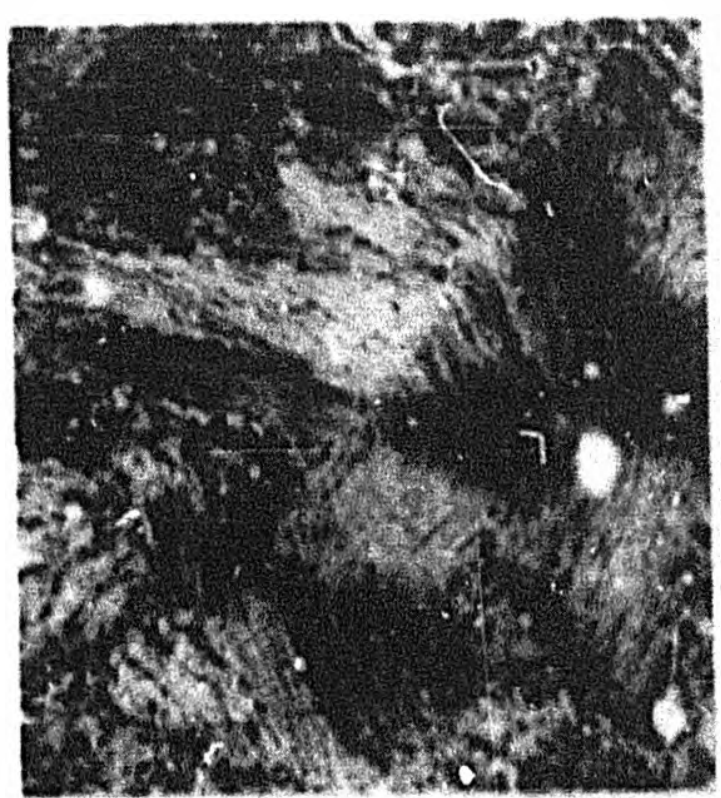

(B) Continuoue Gradetions of Mantecbivity ia Stratifled Katal of Cuter 20ne. Presusally tarecryatalined.

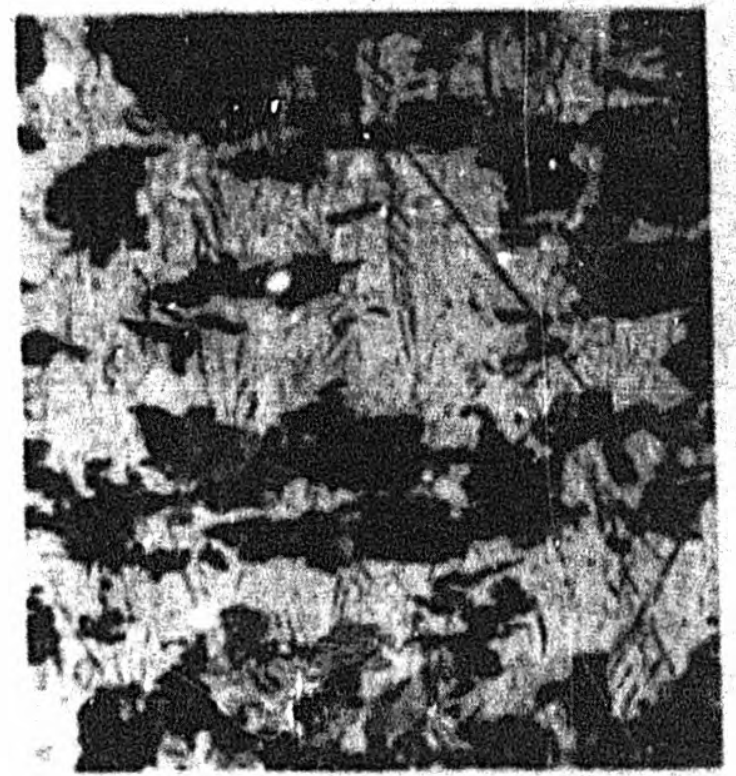

(iv) Orain size st Conter of Inner zone. Sarce pound a in (c). Lorgl tudinal Section.

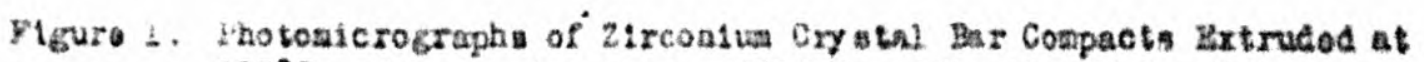
$900^{\circ} \mathrm{C}$ and valer Quenched. $250 \mathrm{x}$ Kagnifleation Under Polarlad inght. 


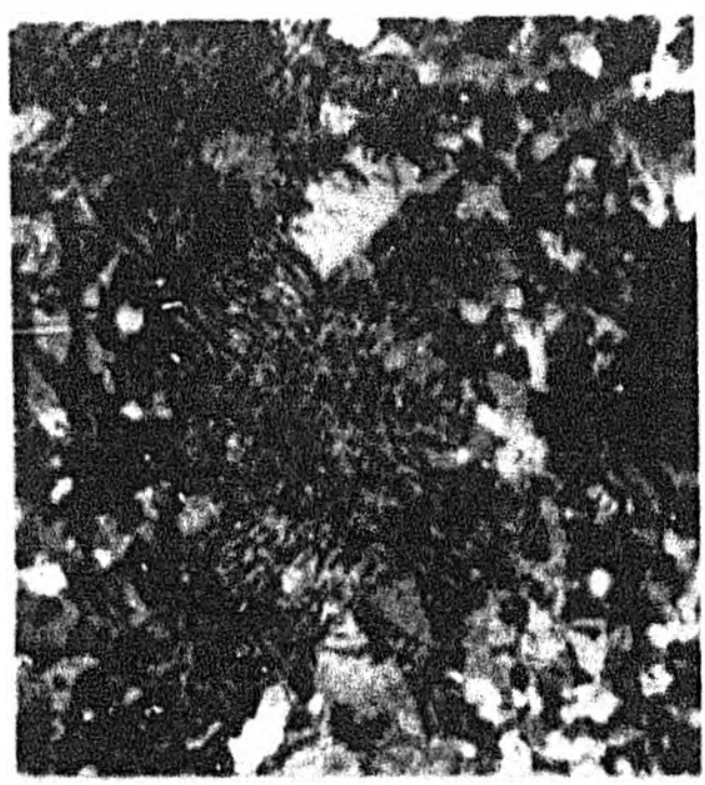

(b) Coureo Oralne eit Center of Inder Zose Shouling Continuous Gradatlong In Reflootivity and Curved Striae Sulsestivo of Unrecrystalliged Metas. $14: 1$ ratuoed Hound, Mater Queached.

Prenoverse Saction

$250 x$

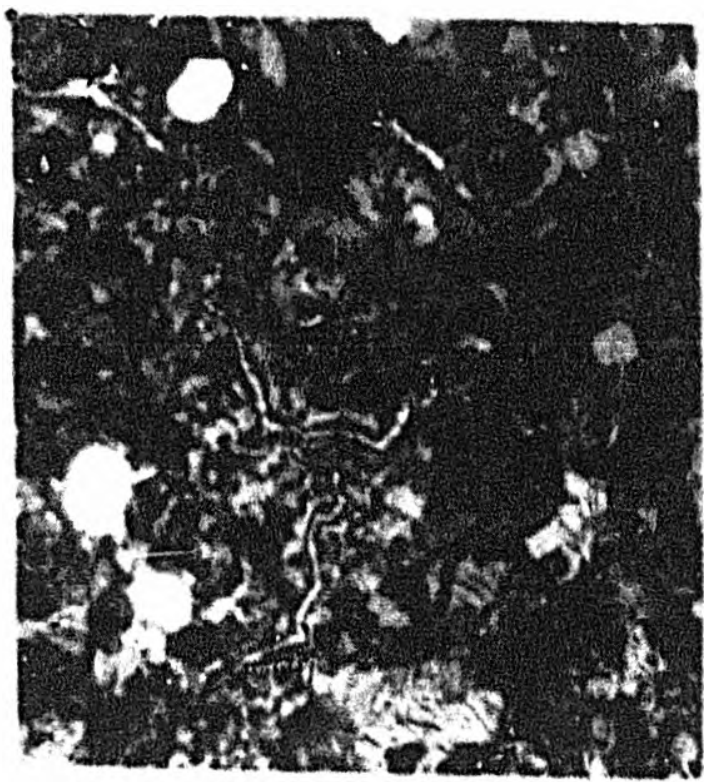

(c) Vartationio in structure hajecent to Unbonded Interface. $14: 1$ Roduced Hound, Hater Qusnctod. Fraseverso sectlon

$250 x$

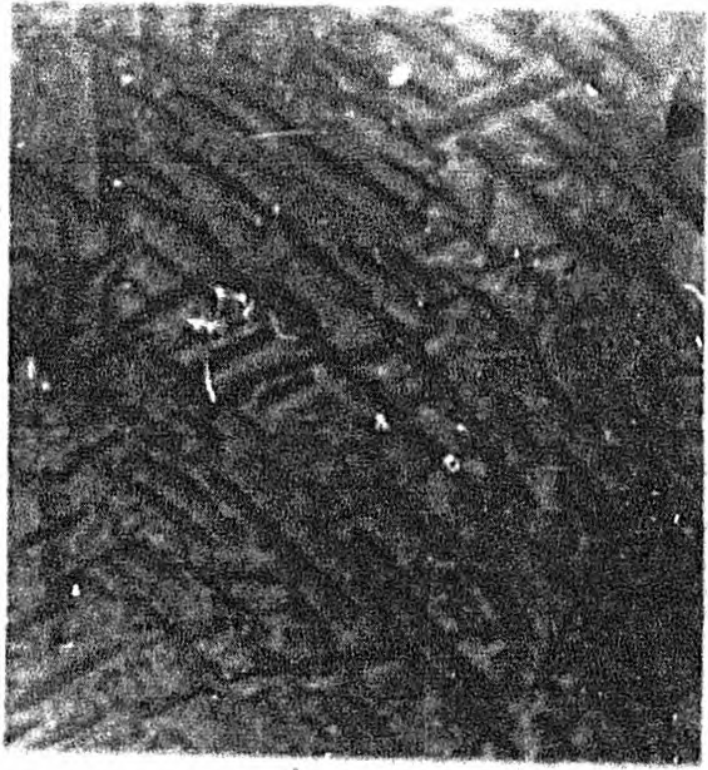

(B) Currod Striae, Seat Soction as in (h).

Brdegt Light

$2500 x$

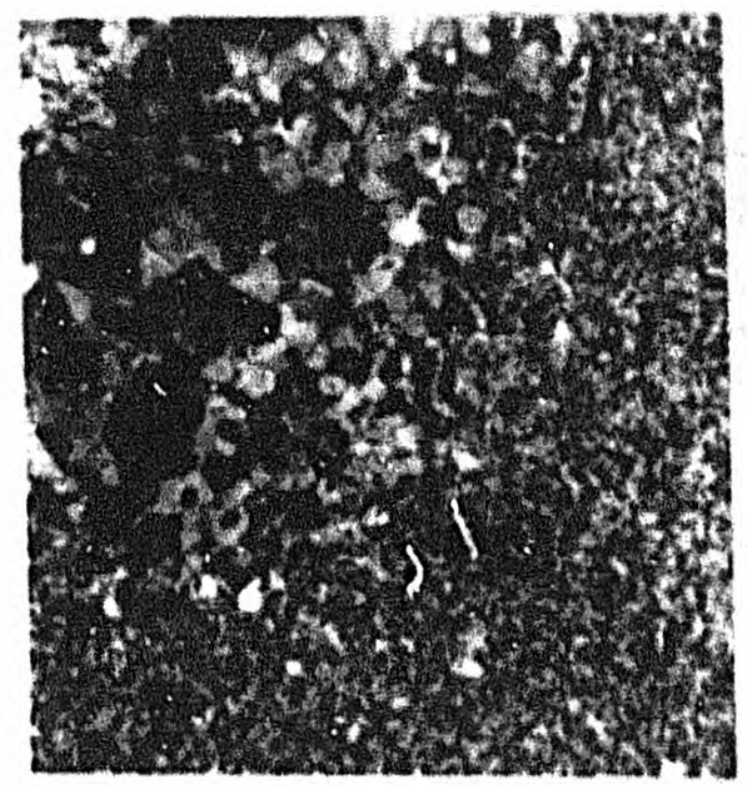

(D) Difrerence in Oraln Sire botween Adjacent Chunks of Cryotal Bar in 31.6i2 Reduced Round. Air Cooled. insueverse Soction $250 x$

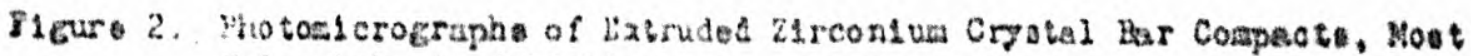
undor folarlzed ideth. 
EFFECT OF COOLING RATE ON

TENSILE PROPERTIES OF

EXTRUDED ZIRCONIUM CRYSTAL.

BAR COMPACTS

\section{- WATER QUENCHED}

- AIR COOLEO

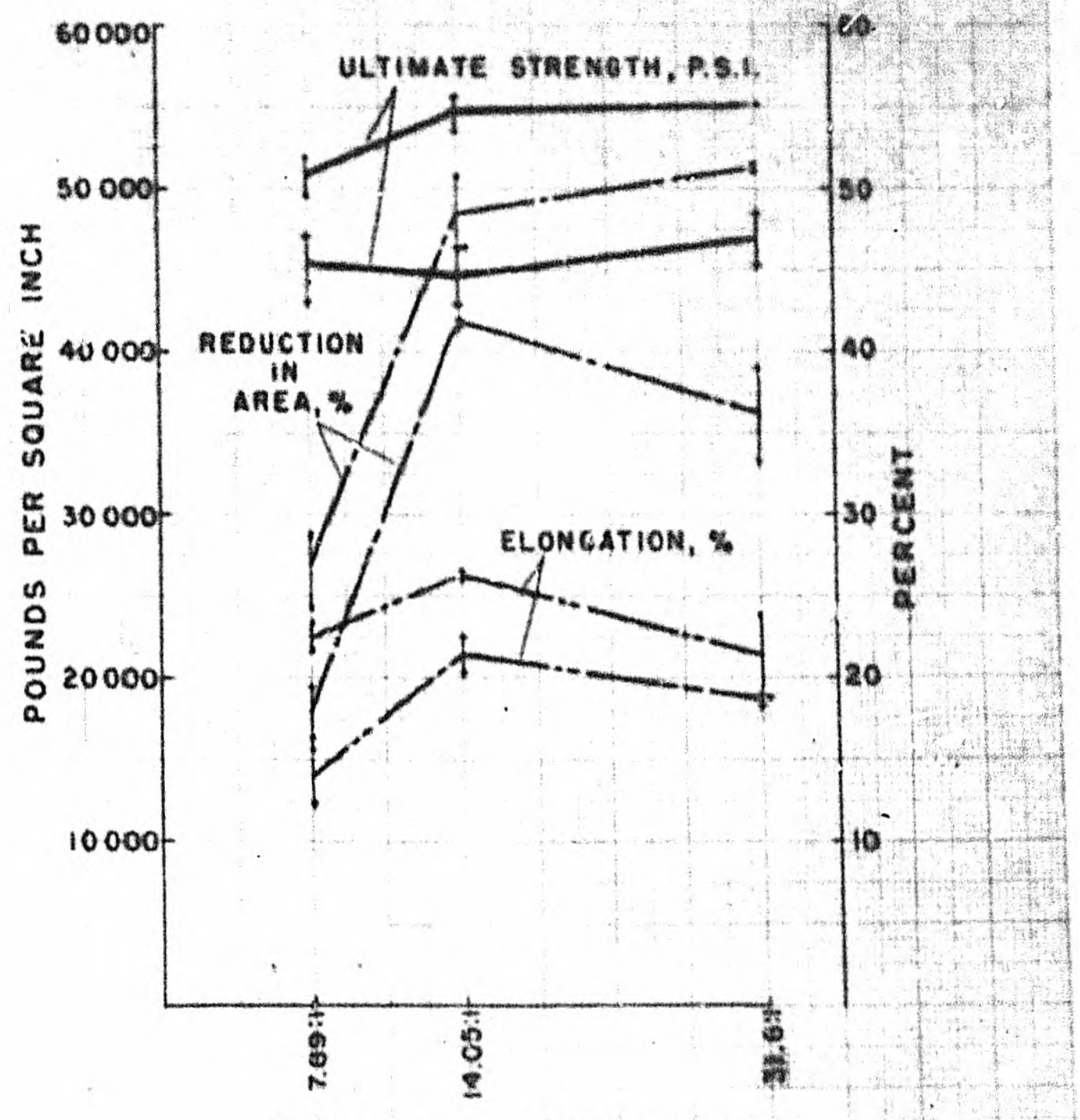

EXTRUSION FEDUCTION RATIO

79. 2

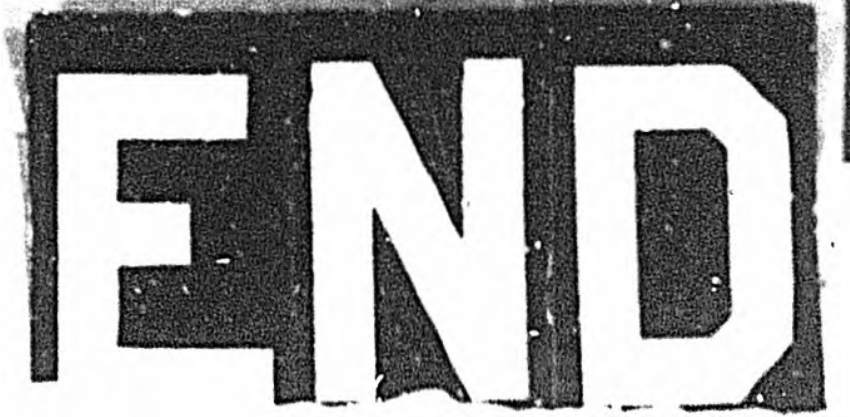

